Oden Krisyan, Retno Sulistiyowati, Kurniawan/ Jurnal Analis Kesehatan Klinikal Sains 9 (1) (2021)

\begin{tabular}{|c|c|c|}
\hline & $\begin{array}{c}\text { Klinikal Sains } 9(1)(2021) \\
\text { JURNAL ANALIS KESEHATAN } \\
\text { KLINIKAL SAINS }\end{array}$ & KLINIKALSAll \\
\hline $\begin{array}{l}\text { UNIVERSITAS } \\
\text { ABDURR AB }\end{array}$ & http://jurnal.univrab.ac.id/index.php/klinikal & 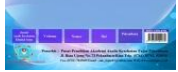 \\
\hline
\end{tabular}

\title{
ANALISIS KADAR RHODAMIN B PADA TERASI YANG DIPERJUALBELIKAN DI PASAR BELIK KABUPATEN PEMALANG
}

\author{
Oden Krisyan, Retno Sulistiyowati, Kurniawan \\ Mahasiswa Program Studi Teknologi Laboratorium Medik, Fakultas Ilmu Kesehatan \\ Program Studi Teknologi Laboratorium Medik, Fakultas Ilmu Kesehatan \\ Universitas Muhammadiyah Purwokerto \\ Jl. Letjen. Soepardjo Roestam Km. 7 PO. BOX 229 Purwokerto 53181. \\ email: krisyan1804@gmail.com
}

\begin{abstract}
Info Artikel Abstrak
Sejarah Artikel:

Terasi adalah bumbu masak yang terbuat dari udang yang telah difermentasikan dan sering ditemukan di pasaran. Harga terasi relatif terjangkau dan mudah dijumpai,

Diterima Februari 2021

Disetujui Juni 2021

Dipublikasikan Juni 2021

Keywords:

rhodamine $B$, shrimp paste, qualitative analysis, food additives sehingga masyarakat memilihnya sebagai penambah cita rasa pada makanan. Masalah penyalahgunaan penambahan Rhodamin $B$ sebagai Bahan Tambahan Pangan (BTP) dalam terasi sering dilakukan oleh pembuat terasi. Tujuan penelitian ini untuk menganalisis kandungan Rhodamin $B$ pada terasi yang diperjualbelikan di Pasar Belik Kabupaten Pemalang. Penelitian ini dilakukan secara observasional deskriptif dimana sampel dianalisis secara kualitatif dan apabila hasilnya positif akan dilanjutkan dengan analisis kuantitatif. Penelitian dilakukan pada bulan Desember 2020. Data kandungan Rhodamin B pada terasi dianalisis dengan uji univariat. Analisis kualitatif dilakukan dengan metode kimiawi menggunakan larutan $\mathrm{NaOH} 10 \%$, Petroleum Eter dan $\mathrm{HCl} \mathrm{10 \%}$. Hasil analisis kualitatif dari 7 sampel terasi udang yang diperjualbelikan di Pasar Belik Kabupaten Pemalang semuanya negatif tidak mengandung Rhodamin B. Sampel terasi udang yang diperjulbelikan di Pasar Belik Kabupaten Pemalang menunjukkan bebas dari zat pewarna Rhodamin $B$.
\end{abstract}

Kata Kunci: Rhodamin B, terasi, analisis kualitatif, bahan tambahan pangan.

\section{Abstract}

Terasi is a cooking spice made from fermented shrimp and is often found in the market. It is relatively affordable and easy to find, so people flavor it as a flavor enhancer for their food. The abuse of Rhodamine B as a Food Additive (BTP) in terasi is often done by the producers. This study aimed to analyze the Rhodamine $B$ content in the terasi sold at the Pasar Belik, Pemalang Regency. The study was conducted in a descriptive observational manner where the sample was analyzed qualitatively and if the result were positive it would be followed by quantitative. The study was conducted in December 2020. Rhodamine B content in tersi was analyzed by univariate test. Qualitative analysis was carried out by chemical methods using $10 \% \mathrm{NaOH}$, Petroleum Eter and 10\% $\mathrm{HCl}$. The results of the qualitative analysis of 7 samples of shrimp paste sold at the Belik Market in Pemalang Regency were all negative and did not contain Rhodamine B. Shrimp samples that were bought and sold at the Pasar Belik in Pemalang Regency showed that they were free from 


\footnotetext{
Alamat korespondensi:

Jl. Letjen. Soepardjo Roestam Km. 7

krisyan1804@gmail.com
}

\section{PENDAHULUAN}

Menurut peraturan Pemerintah RI Nomor 86 Tahun 2019 tentang keamanan pangan, pangan merupakan sumber biologi produk pertanian, perkebunan, baik yang sudah diolah ataupun belum diolah. Keamanan pangan merupakan upaya yang dilakukan untuk menghindari pangan dari cemaran biologis dan kimia. Cemaran pangan merupakan bahan yang tidak sengaja ada dalam pangan yang berasal dari lingkungan. Bahan ini bisa berupa cemaran biologis, cemaran kimia logam berat, mikotoksin dan zat radioaktif, residu obat hewan dan pestisida yang dapat mengganggu dan membahayakan kesehatan manusia.

Perilaku masyarakat sebagai konsumen produk pangan kian berubah seiring dengan perkembangan ilmu pengetahuan dan informasi. Secara umum, produk pangan yang disukai adalah yang memenuhi selera atau citarasa seperti warna, bau dan rasa. Terlebih saat ini konsumen tidak menjadikan rasa sebagai satu-satunya pertimbangan dalam pemilihan konsumsi produk pangan, tetapi juga menuntut produk yang bersifat praktis dan harga yang ekonomis. Alasan inilah yang mendorong produsen untuk menambahkan Bahan Tambahan Pangan (BTP) pada produk pangan (Almatsier, 2002).

Salah satu jenis BTP yang sering digunakan yaitu zat pewarna baik yang bersifat alami maupun sintetis (buatan). Zat pewarna alami diperoleh dari tumbuhan maupun hewan seperti wortel, pepaya, daun pandan, klorofil dan cochineal. Sedangkan untuk bahan sintetis (buatan) diperoleh melalui proses kimia menggunakan bahan-bahan kimia, contohnya: tartrazin, indigotin dan eritrosin (Saparinto et.al., 2006).

Peraturan Menteri Kesehatan RI No. 033 Tahun 2012 Tentang BTP menyebutkan bahwa BTP yang diizinkan penggunaannya adalah pengental, pengeras, penguat rasa, peningkat volume, penstabil, peretensi warna, perisai, perlakuan tepung, sekuestran, pemanis, pengawet, pewarna. BTP yang tidak diizinkan antara lain: asam borat, dulsin, formalin, kalium bromat, asam borat dan senyawanya, kalium klorat, kloramfenikol, minyak nabati yang dibrominasi, nitrofurazon, dulkamara, kokain, Rhodamin $B$. 
Oden Krisyan, Retno Sulistiyowati, Kurniawan/ Jurnal Analis Kesehatan Klinikal Sains 9 (1) (2021)

Rhodamin $B$ adalah bahan yang dilarang dalam kegiatan atau produksi pangan. Senyawa ini memiliki rumus kimia $\mathrm{C} 28 \mathrm{H} 31 \mathrm{~N} 2 \mathrm{O} 3 \mathrm{Cl}$ dan berat molekul 479.000. Ciri-ciri Rhodamin $B$ antara lain berupa serbuk kristal berwarna kehijauan (Berta, 2012). Penambahan zat warna tersebut ke dalam terasi sangat berbahaya apabila masuk kedalam tubuh yang dapat menyebabkan kanker hati (Wijaya, 2011).

Data dari Sentra Informasi Keracunan Nasional sepanjang tahun 2017, insiden keracunan akibat konsumsi makanan menduduki posisi paling tinggi, yaitu 69,2\% dibanding dengan keracunan akibat penyebab lain, misalnya minuman, obat, kosmetik serta pestisida. Kejadian keracunan disebabkan oleh makanan olahan rumah tangga, makanan jalanan, makanan olahan dalam kemasan maupun makanan segar.

Terasi merupakan salah satu jenis bumbu tradisional yang berupa hasil fermentasi ikan atau udang. Bahan yang digunakan dalam pembuatan terasi yaitu udang rebon (Acetes sp.) atau ikan yang melalui proses fermentasi dan penambahan garam. Terasi banyak digunakan untuk meningkatkan rasa, aroma dan selera makan. Penggunaan Rhodamin B pada terasi bertujuan untuk memberikan warna pada terasi agar terlihat lebih menarik (Hariyanto et al., 2013).

Hasil penelitian Giovani et al., (2017) menunjukkan 10 sampel terasi yang dipasarkan di Kota Medan tidak mengandung Rhodamin B. Sedangkan Kumalasari, et al., (2015) menemukan 9 dari 15 sampel terasi yang dipasarkan di Kota Makassar mengandung Rhodamin B dengan kadar tertinggi 19,05 ppm dan kadar terendah 11,81 ppm.

\section{METODE}

Penelitian ini dilakukan secara observasional dengan rancangan deskriptif. Penelitian dilaksanakan di Laboratorium Instruksional Dasar Teknik Kimia Universitas Muhammadiyah Purwokerto pada bulan Desember 2020. Alat yang digunakan dalam penelitian ini antar lain pisau, timbangan analitik, mortar dan pestel, labu ukur, gelas ukur pipet tetes, beaker glass, pipet ukur, tabung reaksi, aluminium foil, sampel terasi udang, bubuk Rhodamin $B, \mathrm{HCl} \mathrm{10 \% ,} \mathrm{NaOH}$ $10 \%$, Petroleum eter. 
Oden Krisyan, Retno Sulistiyowati, Kurniawan/ Jurnal Analis Kesehatan Klinikal Sains 9 (1) (2021)

\section{Prosedur Kerja}

1. Tahap Persiapan

Peneliti melakukan survei awal untuk mendata jumlah penjual, jenis-jenis dan merek terasi yang diperjualbelikan di Pasar Belik Kabupaten Pemalang. Data yang diperoleh digunakan untuk menentukan jumlah sampel yang akan digunakan dalam penelitian ini. Peneliti mengajukan permohonan ijin penelitian di Laboratorium Instruksional Dasar Teknik Kimia Fakultas Teknik dan Sains Universitas Muhammadiyah Purwokerto. Setelah ijin turun, peneliti mengajukan permohonan peminjaman alat dan pembelian bahan habis pakai. Semua peralatan terutama alat gelas dicuci bersih dan dikeringkan.

2. Pengamatan Fisik

Ciri-ciri terasi udang:
a) Bentuk : utuh dan kokoh
b) Tekstur : agak kasar, padat
c) Bau : spesifik (udang)
d) Warna : cokelat kemerahan (BSN, 2009).

3. Tahap Pelaksanaan Penelitian

Mengambil sampel terasi di Pasar Belik Kabupaten Pemalang. Sampel dimasukkan ke dalam kantong plastik kemudian dibawa ke Laboratorium Instruksional Dasar Teknik Kimia Fakultas Teknik Universitas Muhammadiyah Purwokerto. Sampel dipisahkan sesuai dengan merek terasi dan diberi kode.

4. Analisis Kualitatif (Yamlean, 2011)

Sampel dibuka kemasannya untuk kemudian diletakkan di gelas beaker, sampel dipotong menggunakan pisau dan ditimbang sebanyak 2 g kemudian ditumbuk menggunakan mortar dan pestel sampai halus. Sampel dimasukkan kedalam labu ukur untuk kemudian ditambahkan $5 \mathrm{ml}$ larutan $\mathrm{NaOH}$ 10\%, tambahkan $2 \mathrm{ml}$ larutan eter dan dikocok sehingga sampel akan terekstraksi yang dibuktikan dengan terbentuknya dua lapisan yang terpisah, lapisan atas berupa larutan eter yang jermih dan lapisan bawah berupa air yang berwarna kecokelatan. Larutan diamkan beberapa saat agar kedua lapisan benar-benar terpisah, lapisan eter dipindahkan kedalam erlenmeyer ditambahkan $2 \mathrm{ml}$ larutan $\mathrm{HCl} 10 \%$ melalui dinding corong untuk kemudian dikocok secara perlahan. Melakukan pengamatan ada tidaknya perubahan warna dari warna bening menjadi warna merah pada larutan eter setelah penambahan larutan $\mathrm{HCl}$ 10\% Apabila terbentuk warna merah, maka sampel terasi positif mengandung Rhodamin $B$. Tetapi apabila tidak 
Oden Krisyan, Retno Sulistiyowati, Kurniawan/ Jurnal Analis Kesehatan Klinikal Sains 9 (1) (2021) terbentuk warna merah, maka sampel terasi tidak mengandung (negatif) Rhodamin $B$. Hasil pengamatan dicatat, didata dan didokumentasikan di buku logbook penelitian.

\section{HASIL DAN PEMBAHASAN}

Adapun hasil yang diperoleh dapat dilihat pada Tabel 1 .

Tabel 1. Hasil Analisis Kualitatif Kandungan Rhodamin B pada Terasi

\begin{tabular}{|c|c|c|c|}
\hline No. & $\begin{array}{c}\text { Kode } \\
\text { Sampel }\end{array}$ & Hasil & $\begin{array}{c}\text { Interprestasi } \\
\text { Hasil }\end{array}$ \\
\hline 1. & $\mathrm{~T} 1$ & $\begin{array}{l}\text { Sampel filtrat yang ditambahkan dengan } \mathrm{HCl} \\
10 \% \text { tidak ada perubahan warna menjadi merah }\end{array}$ & Negatif (-) \\
\hline 2. & $\mathrm{~T} 2$ & $\begin{array}{l}\text { Sampel filtrat yang ditambahkan dengan } \mathrm{HCl} \\
10 \% \text { tidak ada perubahan warna menjadi merah }\end{array}$ & Negatif (-) \\
\hline 3. & $\mathrm{~T} 3$ & $\begin{array}{l}\text { Sampel filtrat yang ditambahkan dengan } \mathrm{HCl} \\
10 \% \text { tidak ada perubahan warna menjadi merah }\end{array}$ & Negatif (-) \\
\hline 4. & $\mathrm{~T} 4$ & $\begin{array}{l}\text { Sampel filtrat yang ditambahkan dengan } \mathrm{HCl} \\
10 \% \text { tidak ada perubahan warna menjadi merah }\end{array}$ & Negatif (-) \\
\hline 5. & $\mathrm{~T} 5$ & $\begin{array}{l}\text { Sampel filtrat yang ditambahkan dengan } \mathrm{HCl} \\
10 \% \text { tidak ada perubahan warna menjadi merah }\end{array}$ & Negatif (-) \\
\hline 6. & T6 & $\begin{array}{l}\text { Sampel filtrat yang ditambahkan dengan } \mathrm{HCl} \\
10 \% \text { tidak ada perubahan warna menjadi merah }\end{array}$ & Negatif (-) \\
\hline 7. & $\mathrm{~T} 7$ & $\begin{array}{l}\text { Sampel filtrat yang ditambahkan dengan } \mathrm{HCl} \\
10 \% \text { tidak ada perubahan warna menjadi merah }\end{array}$ & Negatif (-) \\
\hline
\end{tabular}

Tabel 2. Komposisi Sampel Terasi

\begin{tabular}{lll}
\hline No & Kode Sampel & Komposisi \\
\hline 1 & T1 & Udang rebon, garam \\
2 & T2 & Udang rebon, garam \\
3 & T3 & Udang rebon, garam \\
4 & T4 & Udang rebon, garam \\
5 & T5 & Udang rebon, garam \\
6 & T6 & Tidak diketahui \\
7 & T7 & Tidak diketahui \\
\hline
\end{tabular}


Oden Krisyan, Retno Sulistiyowati, Kurniawan/ Jurnal Analis Kesehatan Klinikal Sains 9 (1) (2021)

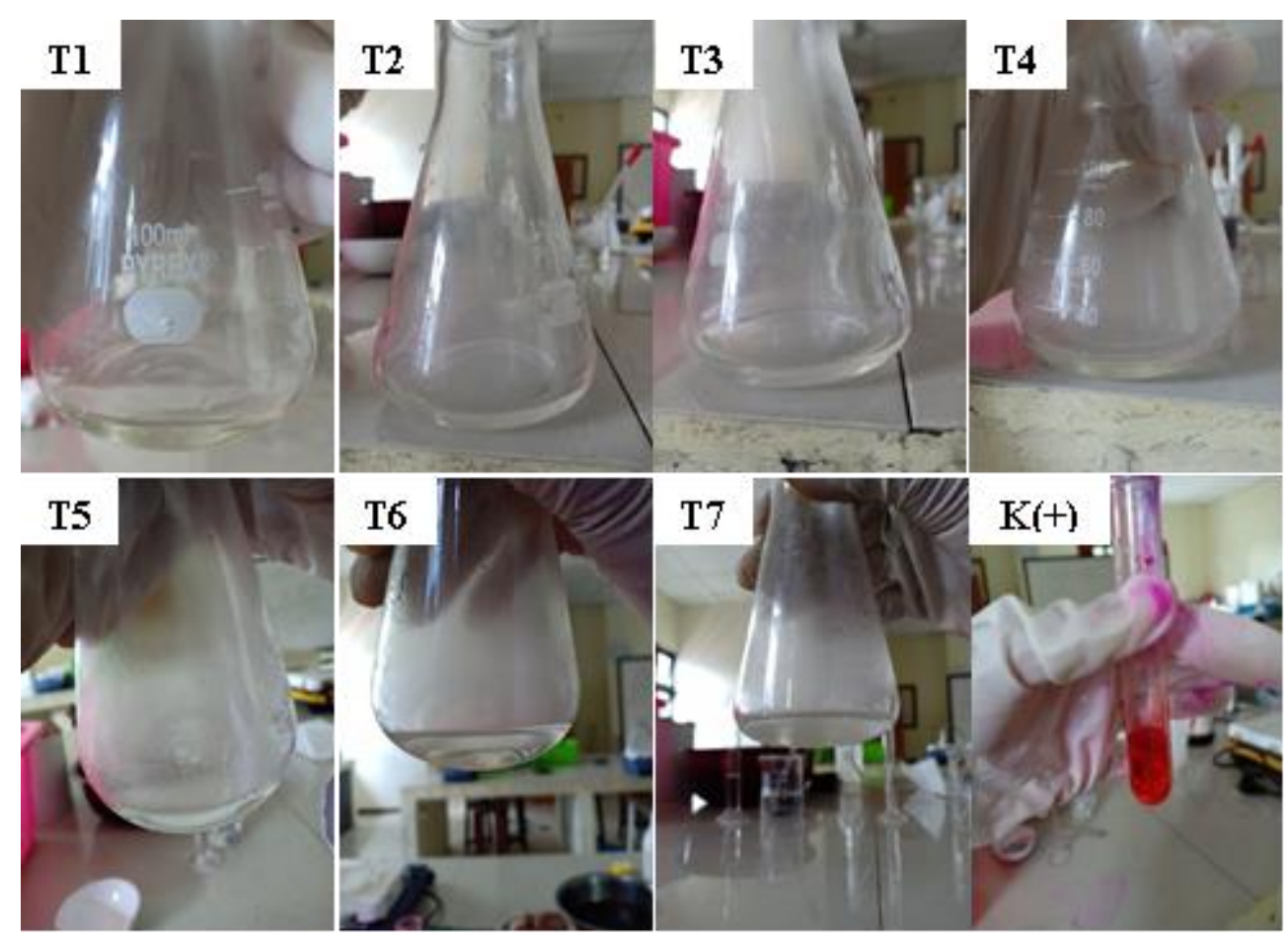

Gambar 4.2. Hasil Analisis Kualitatif Sampel T1-T7 dan Kontrol Positif

Analisis kandungan Rhodamin $B$ pada terasi udang dilakukan dengan memanfaatkan larutan $\mathrm{NaOH} 10 \%$, petroleum ether dan $\mathrm{HCl} 10 \%$. $\mathrm{NaOH}$ merupakan larutan yang bersifat basa, berwarna putih dan berfungsi sebagai pelarut basa. Petroleum ether adalah pelarut non polar yang bersifat mudah menguap. Pelarut ini berfungsi sebagai penghilang lemak dan pengekstraksi zat warna Rhodamin $B$ dalam lingkungan basa. Asam klorida $(\mathrm{HCl})$ adalah senyawa kimia yang bersifat asam kuat yang berfungsi sebagai pengekstraksi asam dan menguji kandungan Rhodamin B. Perubahan warna dan terbentuknya endapan merah pada sampel menunjukkan adanya reaksi yang terjadi antara larutan $\mathrm{HCl}$ 10\% dan Rhodamin B (Sugiyarto, 2003).

Hasil penelitian ini tidak menemukan sampel terasi udang yang mengandung Rhodamin $B$. Terasi memiliki warna khas cokelat, warna tersebut dipengaruhi oleh astaxanthin pada cangkang udang. Hal ini bahwa terasi yang memiliki warna merah belum tentu terdapat Rhodamin $B$ melainkan dipengaruhi oleh pigmen astaxanthin serta banyak sedikitnya konsentrasi garam yang diberikan pada saat fermentasi (Suprapti, 2006). Menurut Jin, et al., (2013) astaxanthin pada konsentrasi garam tinggi (15\%) jumlahnya lebih sedikit dibandingkan dengan astaxanthin pada konsentrasi garam rendah (2-8\%) sehingga terasi menjadi hitam seperti pada sampel T6, sedangkan pada sampel T7 memiliki warna merah kehitaman karena menggunakan konsentrasi garam yang rendah. Adawyah (2007) menyampaikan bahwa garam 
Oden Krisyan, Retno Sulistiyowati, Kurniawan/ Jurnal Analis Kesehatan Klinikal Sains 9 (1) (2021) tidak hanya digunakan sebagai penambah cita rasa namun memiliki peran lain, yaitu meningkatkan nilai gizi serta memantapkan bentuk dan rupa.

Pembuatan terasi banyak dilakukan oleh penduduk secara tradisional seperti pada sampel T6 dan T7 sehigga komposisi terasi tidak diketahui pada kemasan. Berbeda dengan terasi yang diproduksi oleh pabrik, komposisi tertera pada kemasan dan disetujui oleh BPOM

\section{SIMPULAN}

Berdasarkan hasil penelitian dan pembahasan di atas, maka dapat diambil kesimpulan sebagai berikut:

1. Hasil analisis kualitatif semua sampel terasi udang yang diperjulbelikan di Pasar Belik Kabupaten Pemalang menunjukkan bebas dari zat pewarna Rhodamin B.

2. Analisis kuantitatif dan perhitungan kadar Rhodamin $B$ tidak dilakukan karena sampel tidak mengandung Rhodamin B.

\section{UCAPAN TERIMA KASIH}

Peneliti mengucapkan terimakasih kepada kedua orang tua, dosen pembimbing dan teman-teman yang sudah memberikan dukungan dan bantuannya dalam menyelesaikan penelitian ini.

\section{DAFTAR PUSTAKA}

Adawyah, R. 2007. Pengolahan dan Pengawetan Ikan. Bumi Aksara, Jakarta.

Afrianto E. dan Liviawaty, E. 1991. Pengawetan dan Pengolahan Ikan. Kanisius, Yogyakarta.

Almatsier, S. 2002. Prinsip Dasar Ilmu Gizi. Jakarta: Gramedia Pustaka

Badan Standardisasi Nasional. 2009. Terasi Udang Bagian 1. Badan Standardisasi Nasional Indonesia (BSNI). Jakarta.

Berta K, Taufik A \& Wirsal H. 2012. Karakteristik Pedagang Sanitasi Pengolahan dan Analisa Kandungan Rhodamin B pada Bumbu Cabai Giling di Pasar Tradisonal Kecamatan Medan Baru. Fakultas Kesehatan Masyarakat. Universitas Sumatera Utara.

Giovani, M.B.L., Jemmy, A., dan Novel, S.K. 2017. Analisis Zat Pwarna Rhodamin B Pada Saos Bakso Tusuk Yang Beredar Di Sekitar Kampus Universitas Sam Ratulangi Manado. Jurnal Ilmiah Farmasi, vol.6

Hariyanto, N., Dwi R., dan Hery K. 2013. Upaya Peningkatan Kualitas dan Produksi Pencacahan Udang Rebon Menjadi Terasi dengan Aplikasi Mesin Extruder. Universitas Diponegoro, Semarang, $24 \mathrm{hlm}$. 
Oden Krisyan, Retno Sulistiyowati, Kurniawan/ Jurnal Analis Kesehatan Klinikal Sains 9 (1) (2021)

Jin,G., He,L., Yu,X., Zhang,J. and Ma,M. 2013. Antioxidant Enzyme Activities are Affected by Salt Content, Temperature\& Influence Muscle Lipid Oxidation During Dry-Salted Bacon Processing. Journal Food Chemistry 141

Kumalasari, E. (2015). Identifikasi dan Penetapan Kadar Rhodamin B dalam Kerupuk Berwarna Merah yang Beredar di Pasar Antasari Kota Banjarmasin. Journal Il.

Peraturan Menteri Kesehatan No. 33. 2012. Bahan Tambahan Pangan. Jakarta: Kementerian Kesehatan Republik Indonesia.

Peraturan Pemerintah RI Nomor 86. 2019. Keamanan Pangan. Jakarta.

Saparinto, C dan Hidayat, D. 2006. Bahan Tambahan Pangan. Yogyakarta: Penerbit Kanisius.

Sugiyarto, H. 2003. Dasar-Dasar Kimia Anorganik Logam. Jakarta

Suprapti, M. L. 2006. Teknologi Tepat Guna: Membuat Terasi. Kanisius, Yogyakarta. 